Journal of Animal and Veterinary Advances $10(4)$ : 480-483, 2011

ISSN: $1680-5593$

(C) Medwell Journals, 2011

\title{
Expression of Augmenter of Liver Regeneration and Nuclear Faction- $K B$ in Human Hepatocellular Carcinoma
}

\author{
Zhang Aimin and Shen Shiqiang \\ Department of General Surgery, Renmin Hospital of Wuhan Univesity, 430060 Wuhan, China
}

\begin{abstract}
To determine whether the levels of expression of the Augmenter of Liver Regeneration (ALR) and nuclear faction- $\mathrm{kB}(\mathrm{NF}-\mathrm{kB})$ were assoiated with the clinicopathological features in human Hepatocellular Carcinoma (HCC). Gene expression was measured by using RT-PCR in the 30 human HCC tissues, matched adjacent tissues and 8 normal hepatic tissues. The clinicopathological data of all patients were also collected. Higher expression of ALR mRNA was observed in HCC tissues compared with normal liver tissue ( $<<0.05)$, it did not differ from the expression of matching non-neoplastic tissue in the same patient ( $p>0.05$ ). Expression of both two genes were not found to be significantly associated with clinical/pathologic factors. $(p>0.05)$. The expression of ALR mRNA in HCC tissues was positively correlated with NF- $\mathrm{kB}$ mRNA $(\mathrm{r}=0.382, \mathrm{p}<0.05)$. Up-regulation of ALR may play partial role of carcinogenesis through MAPK pathway in HCC.
\end{abstract}

Key words: Augmenter of liver regeneration, hepatocellular carcinoma, nuclear faction- $\mathrm{kB}$, partial role, clinicopathological, China

\section{INTRODUCTION}

Augmenter of Liver Regeneration (ALR), a kind of polypeptide is mainly produced and stored in parenchymal cells. It has been proved that a large number of acceptors of ALR exist on the surface of hepatic cells. Little is known about the expression of ALR in Hepatocellular Carcinoma (HCC). Nuclear faction- $\mathrm{kB}$ (NF-kB) has the function of anti-apoptosis. The correlation of these two in HCC has not been reported. The aim of this study, conducted in a series of patients diagnosed with $\mathrm{HCC}$ was therefore to determine the relation between the clinical/pathologic factors and the levels of gene expression of ALR and NF- $\mathrm{kB}$.

\section{MATERIALS AND METHODS}

Patients and tissue specimens: The present study was based on 30 patients of $\mathrm{HCC}$ for whom tumor tissue was available between 2007 and 2008. The fresh HCC sample and matched paracancerous tissues were obtained from several teaching hospitals in Wuhan.

The paracancerous tissue was $3 \mathrm{~cm}$ from tumor fringe. Eight cases of normal hepatic tissues were obtained from hepatorrhexis patients. All samples were qualified by histology. Samples were rapidly frozen in liquid nitrogen and stored at $-80^{\circ} \mathrm{C}$. Peripheral blood samples were also collected before operation. About 21 cases were males and 9 cases were females, median age at diagnosis was 54 years (rang, 35-76) with no previous radiotherapy and chemotherapy.

Materials: The following reagents were used in this study: Trizol reagents (Invitrogen, Carlsbad, CA,USA); cDNA primer linkage synthetic kit (Fermentas, Lithuania); The primers, PCR kit (Sai Baisheng Gene Limited Company, Shanghai, Chian). The PCR amplification meter (Mannheim, Germany).

RNA isolation: About $100 \mathrm{mg}$ of each tissue sample was homogenized on ice in $1 \mathrm{~mL}$ Trizol reagent using a DEPC treated homogenizer. Total RNA was then extracted using a one-step RNA isolation technique. About $50 \mu \mathrm{L}$ RNasefree solution was added to the collected RNA before storing at $-70^{\circ} \mathrm{C}$. After diluting $12 \mu \mathrm{L}$ RNA sample in $3 \mathrm{~mL}$ DEPC-treated water, the concentration and purity of each sample was evaluated using a UV 240 spectrophotometer. The A260/A280 absorbance ratio of the RNA samples ranged from 1.9-2.0.

Primer design: The following primers were purchased from Sai Baisheng Gene Limited Company. ALR forward primer: 5'-AAGCGGGACACCAAGTTTAGG-3', reverse primer: 5'-CAGCTTGCGG TTCA CTTC-3' with $288 \mathrm{bp}$ for amplification. NF- $\mathrm{kB}$ forward primer: 5'-AAAGGTTAGGGTCAAGAT-3', reverse primer:

Corresponding Author: Shen Shiqiang, Department of General Surgery, Renmin Hospital of Wuhan Univesity, 430060 Wuhan, China 
5'-TAGGAATTGCAGGTGTAT-3' with 405 bp for 5'-CTGGGACGACATGGAGAAAAT-3', reverse primer: 5'-AGGAAGGAAGGCTGGAAGAGT-3' with 567 bp for amplification.

Reverse transcription: RNA samples were reverse transcribed using a $20 \mu \mathrm{L}$ reverse transcription reaction system. About $4 \mu \mathrm{L}$ RNA, $1 \mu \mathrm{L}$ of oligo $(\mathrm{dT})_{18}$ and $7 \mu \mathrm{L}$ of DEPC-treated water were added into an EP tube and incubated at $70^{\circ} \mathrm{C}$ for $5 \mathrm{~min}$. The EP tube was then transferred onto ice and the following reagents were added: $4 \mu \mathrm{L} 5 \times$ buffer, $1 \mu \mathrm{L}$ RNasin and $2 \mu \mathrm{L} 10 \mathrm{mMdNTP}$ mix. The reaction mix was centrifuged down and incubated at $37^{\circ} \mathrm{C}$ for $5 \mathrm{~min}$ after which $1 \mu \mathrm{L} \mathrm{M}-\mathrm{MuLV}$ reverse transcriptase $\left(200 \mu \mu \mathrm{L}^{-1}\right)$ was added. After centrifuging, the final reaction mix was incubated at $42^{\circ} \mathrm{C}$ for $1 \mathrm{~h}$ followed by $70^{\circ} \mathrm{C}$ for $10 \mathrm{~min}$. The product was stored at $-20^{\circ} \mathrm{C}$.

PCR: The suitable PCR conditions and cycle number were determined during a preliminary experiment to amplify genes Tankyrase 1, TRF 1 and hTeRT. The $\beta$-Actin gene was used as an endogenous control gene. The reaction mix contained $2 \mu \mathrm{L}$ cDNA, $2 \mu \mathrm{L}$ each of forward and reverse primers, $4 \mu \mathrm{L}$ of $\mathrm{dNTP}(10 \mathrm{mM}), 5 \mu \mathrm{L}$ of 10× PCRBuffer (within $\mathrm{Mg}^{2+}$ ) and $2 \mu \mathrm{L}$ of TaqDNA polymerase $\left(5 \mathrm{U} \mu \mathrm{L}^{-1}\right)$ in a total volume of $50 \mu \mathrm{L}$, added DEPC-treated water to total volume of $50 \mu \mathrm{L}$. The PCR conditions were as follows: initial denaturation of $94^{\circ} \mathrm{C}$ for $5 \mathrm{~min}$ followed by 30 cycles of $94^{\circ} \mathrm{C}$ for $30 \mathrm{sec}, 55^{\circ} \mathrm{C}$ for $45 \mathrm{sec}, 72^{\circ} \mathrm{C}$ for $60 \mathrm{sec}$ (denaturation) and $72^{\circ} \mathrm{C}$ for $5 \mathrm{~min}$ (annealing and elongation) and finished with a $4^{\circ} \mathrm{C}$ hold for $5 \mathrm{~min}$. The reaction terminated during the $\log$ phase of amplification.

Gel electrophoresis: About $10 \mu \mathrm{L}$ product of PCR was separated through $1.5 \%$ agarose gel and the bands analyzed using the EDAS290 electrophoresis imaging system and Kodak 1D3.5 Image Analysis Software.

Statistical analysis: SPSS13.0 statistics software was used for t-test, paired t-test and Spearman correlationt analysis.

\section{RESULTS AND DISCUSSION}

Expression of ALR and NF-kB mRNA: Expression level of ALR mRNA was $1.32 \pm 0.41$ in HCC tissue, $1.18 \pm 0.33$ in paracancerous tissue and $0.27 \pm 0.13$ in normal tissue. The expression of NF- $\mathrm{kB}$ mRNA was $0.96 \pm 0.21$ in $\mathrm{HCC}$, $0.77 \pm 0.27$ in paracancerous tissue and $0.56 \pm 0.24$ in normal tissue. Although, there were no significant difference in

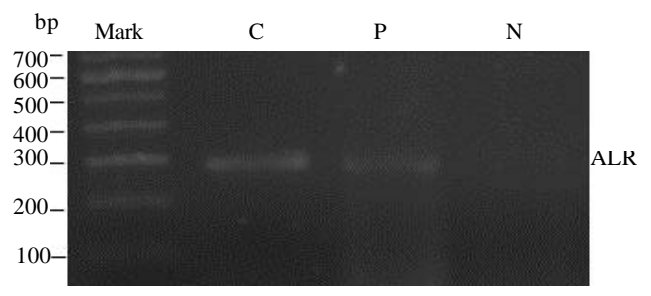

Fig. 1: The expression of ALRmRNA in HCC, peficancerous tissue and normal tissue $(\mathrm{C}$ : $\mathrm{HCC}$, P: Peficancerous tissues; $\mathrm{N}$ : control group)

ALR and NF- $k B$ mRNA expression between $\mathrm{HCC}$ and paracancerous tissues, the level of both of them in HCC tissues was much higher than normal tissue $(\mathrm{p}<0.01)$ (Fig. 1).

Relationship between the expression of ALR mRNA and clinicopathological features: No significant association of ALR mRNA expression was identified with hepatic cirrhosis, HbsAg $(+)$, tumor size, number of tumors, Child-Pugh classification before operation, TNM staging, Edmondson classification and serum AFP level of the patients ( $p>0.05)$ (Table 1 and Fig. 2).

Correlation between the expression of ALR and NF-kB: The expression of ALR mRNA in HCC tissue was positively correlated with NF- $\mathrm{kB}$ mRNA $(\mathrm{r}=0.382$, $\mathrm{p}<0.05$ ).

ALR which was first discovered in partial liver resections of rats is not normally expressed in human liver tissue but is present in cirrhotic liver tissue. It was recently found that ALR can stimulate the proliferation of hepatocytes directly (Liu et al., 2004) and also functions as a disulphide oxidase using thioloxidase as a reductant to inhibit the proliferation of inflammatory cells. This study showed that ALR expression in HCC tissue was significantly elevated compared to normal liver tissue but its expression levels was not higher than the matching paracacinoma tissues in the same patients. These results coincided with the findings of Thasler et al. (2005). This suggests that some stimulator would enhance the expression of ALR in liver, advance activation of MAPK and phosphorylation of EGFR during the process of cell mitosis and thus accelerate the proliferation of cells (Polimeno et al., 2000).

At the same time, it was discovered that injecting ALR into the integrated liver of normal rats can inhibit activity of NK cells (Lewis et al., 2000). It can then be hypothesized that in addition to uncontrollable hepatocyte proliferation, high expressions of ALR may contribute to immune escape of cancerous cells. 


\begin{tabular}{|c|c|c|c|c|c|}
\hline \multirow{2}{*}{$\begin{array}{l}\text { Clinical } \\
\text { pathol ogy }\end{array}$} & \multirow[b]{2}{*}{ Case (n) } & \multicolumn{2}{|c|}{ Strength of ALRmRNA } & \multicolumn{2}{|c|}{ Strength of $N F-K B m R N A$} \\
\hline & & $\mathrm{HCC}$ & $\mathrm{P}$ & $\mathrm{HCC}$ & $\mathrm{P}$ \\
\hline \multicolumn{6}{|l|}{ Hepatitis } \\
\hline HBsAg+ & 23 & $1.42 \pm 0.33$ & & $1.10 \pm 0.31$ & \\
\hline HBsAg- & 7 & $1.27 \pm 0.41$ & 0.3275 & $0.89 \pm 0.18$ & 0.1013 \\
\hline \multicolumn{6}{|l|}{ Corrhosis } \\
\hline Yes & 21 & $1.37 \pm 0.15$ & & $0.93 \pm 0.15$ & \\
\hline No & 9 & $1.24 \pm 0.23$ & 0.0752 & $1.07 \pm 0.22$ & 0.0517 \\
\hline \multicolumn{6}{|l|}{ AFP } \\
\hline$\leq 400 \mu \mathrm{g} \mathrm{L}^{-1}$ & 9 & $1.16 \pm 0.50$ & & $1.13 \pm 0.26$ & \\
\hline$>400 \mu \mathrm{g} \mathrm{L}^{-1}$ & 21 & $1.38 \pm 0.57$ & 0.3248 & $0.91 \pm 0.28$ & 0.0539 \\
\hline \multicolumn{6}{|l|}{ Size } \\
\hline$\leq 5 \mathrm{~cm}$ & 10 & $1.09 \pm 0.47$ & & $0.85 \pm 0.41$ & \\
\hline$>5 \mathrm{~cm}$ & 20 & $1.42 \pm 0.58$ & 0.1306 & $1.01 \pm 0.11$ & 0.1089 \\
\hline \multicolumn{6}{|l|}{ Envelope } \\
\hline+ & 17 & $1.57 \pm 0.63$ & & $1.18 \pm 0.53$ & \\
\hline - & 13 & $1.27 \pm 0.31$ & 0.0564 & $0.92 \pm 0.13$ & 0.0959 \\
\hline \multicolumn{6}{|c|}{ Tumor number } \\
\hline Single & 25 & $1.40 \pm 0.44$ & & $1.01 \pm 0.40$ & \\
\hline Multi & 5 & $1.32 \pm 0.61$ & 0.5753 & $0.95 \pm 0.15$ & 0.7426 \\
\hline \multicolumn{6}{|l|}{ TNM } \\
\hline I--II & 12 & $1.29 \pm 0.36$ & & $0.93 \pm 0.12$ & \\
\hline III--IV & 18 & $1.71 \pm 0.65$ & 0.0607 & $1.08 \pm 0.2$ & 0.0641 \\
\hline
\end{tabular}

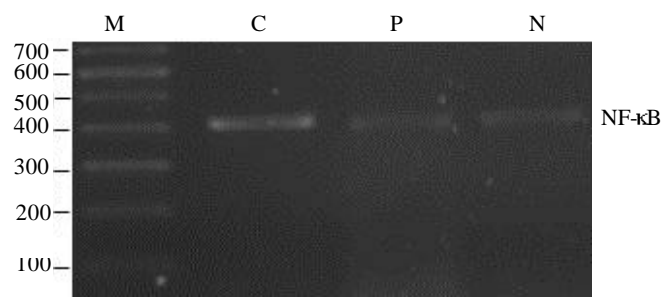

Fig. 2: The expression of NF-kBmRNA in $\mathrm{HCC}$, peficancerous tissue and normal tissue $(\mathrm{C}$ : $\mathrm{HCC}$; P: Peficancerous tissues; N: Control group)

Therefore, ALR may be involved in the pathogenesis of HCC. The results of this study indicated that there was no correlation between the expression of ALR and hepatic cirrhosis, HbsAg (+), tumor size, number of tumors, Child-Pugh classification before operation, TNM staging, Edmondson classification and serum AFP level in HCC ( $\mathrm{p}>0.05$ ). It not only suggested that $\mathrm{HCC}$ is a complex neoplasm regulated by multiple genes but also implied that ALR may play a promotive role in proliferation of $\mathrm{HCC}$ cell. ALR does not induce proliferation in normal hepatocytes directly but can promote proliferation via Kupffer cells (Wang et al., 2006). This may suggest that ALR can indirectly promote regeneration of the liver via inflammatory factors. NF- $\mathrm{KB}$ is a ubiquitous inflammatory factor.

It has 5 isoforms and a diverse range of biological functions including playing a role in inflammatory reactions (Ogata et al., 2004) blood vessels regeneration and apoptosis. The expression of NF- $\mathrm{BB}$ in $\mathrm{HCC}$ is significantly higher than that of normal tissue. However, there was no significant difference between $\mathrm{HCC}$ and adjacent tissue. The adjacent tissue had more or less of inflammation or fibrosis and the histopathology was different from the normal tissue. This may partly explain that there was no significant difference in expression of $\mathrm{NF}-\kappa \mathrm{B}$ between $\mathrm{HCC}$ and adjacent tissue.

High levels of NF- $\mathrm{kB}$ promote the expression of TNF- $\alpha$, L-6, CRP and PAI-I (Zamara et al., 2004). TNF- $\alpha$ and IL- 6 are important mitotic factors in liver regeneration and may therefore advance malignant proliferation of tumor cells. At the same time, the another function of $\mathrm{NF}-\kappa \mathrm{B}$ is anti-apoptotic.

Therefore, it can be implied from above that NF- $k B$ may also play an important role in cancer development and in particular, HCC. Zheng et al. (2008) found that interrupting the expression of NF- $\mathrm{BB}$ can inhibit proliferation and promote apoptosis of tumor cells (Zheng et al., 2008), indicating that NF- $\mathrm{kB}$ can be used as a new target point in gene therapy. Up-regulation of ALR expression increases the activity of MAPK which increases the activity of NF-kB (Lu et al., 2002).

\section{CONCLUSION}

The upregulation of ALR in HCC possibly allows, indirectly, the proliferation of cancerous cells unimpeded by an immune response. ALR also up-regulates the activity of $\mathrm{NF}-\mathrm{kB}$ and thus allows cancerous cells to escape apoptosis.

This synergetic effect is a possible pathaphysiology behind the malignant proliferation of cancerous cells. However, whilst ALR has anti-inflammatory properties, $\mathrm{NF}-\kappa \mathrm{B}$ promotes an inflammatory response. The fact that the expression of both ALR and NF- $\mathrm{kB}$ are $\mathrm{u}$ p-regulated in $\mathrm{HCC}$ shows the complexity of $\mathrm{HCC}$ development. The interaction of ALR and NF-kB in $\mathrm{HCC}$ is still under discussion.

\section{REFERENCES}

Lewis, T., L. Zsak, T.G. Burrage, Z. Lu, G.F. Kutish, J.G. Neilan and D.L. Rock, 2000. An African swine fever virus ERV1-ALR homologue, 9GL, affects virion maturation and viral growth in macrophages and viral virulence in swine. J. Virol., 74: 1275-1285.

Liu, Q., H.F. Yu and H. Sun, 2004. Expression of human augmenter of liver regeneration in pichia pastoris yeast and its bioactivity in vitro. World J. Gastroenterol., 106: 3188-3190. 
Lu, C., Y. Li, Y. Zhao, H. Chen and F. He et al., 2002. Intracrine hepatopoietin potentiates AP-1 activity through JAB1 independent of MAPK pathway. FASEB J., 16: 90-92.

Ogata, T.,T. Miyauchi,S. Sakai,M. Takanashi, Y. Irukayama and I. Yamaguchi,Ogata, T., T. Miyauchi,S. Sakai,M. Takanashi, Y. Irukayama and I. Yamaguchi, 2004. Myocardial fibrosis and diastolic dysfunction in deoxycorticosterone acetate-salt hypertensive rats is ameliorated by the peroxisome proliferator-activated receptor-alpha activator fenofibrate,partly by suppressing inflammatory responses associated with the nuclear factor-kappa-B pathway. J. Am. Coll. Cardiol., 43: 1481-1488.

Polimeno, L., M. Margiotta, R. Francavilla, A. Francavilla and L. Marangi et al., 2000. Molecular mechanisms of augmenter of liver regeneration as immunoregulator: Its effect on interferon-gamma expression in rat liver. Dig. Liver Dis., 32: 217-225.
Thasler, W.E., T. Schlott, K.W. Jauch, T.S. Weiss and P. Thelen et al., 2005. Expression of augmenter of liver regeneration (ALR) in human liver cirrhosis and carcinoma. Histopathol., 47: 57-66.

Wang, C.P., L. Zhou, S.H. Su, Y.Y. Feng and Y.P. Yang et al., 2006. Augmenter of liver regeneration promotes hepatocyte proliferation induced by Kupffer cells. World J. Gastroenterol., 12: 4859-4865.

Zamara, E., E. Novo, F. Marra, M. Pinzani and M. Parola et al., 2004. 4-Hydroxynonenal as a selective pro-fibrogenic stimulus for activated human hepatic stellate cells. J. hepatol., 40: 60-68.

Zheng, X., R.L. Chang and X.X. Cui, 2008. Inhibition of NF-kappaB by (E)3-[(4-methylphenyl)sulfonyl] -2-propenenitrile (BAY11-7082; BAY) is associated with enhanced 12-O-tetradecanoylphorb ol13-acetate- induced growth suppression and apoptosis in human prostate cancer PC-3 cells. Int. J. Oncol., 32: $257-264$. 